Article

\title{
Impacts of Digital Technostress and Digital Technology Self-Efficacy on Fintech Usage Intention of Chinese Gen Z Consumers
}

\author{
You-Kyung Lee
}

check for

updates

Citation: Lee, Y.-K. Impacts of Digital Technostress and Digital Technology Self-Efficacy on Fintech Usage Intention of Chinese Gen Z Consumers. Sustainability 2021, 13, 5077. https://doi.org/10.3390/ su13095077

\section{Academic Editors: Salvador}

Cruz Rambaud, Joaquín López

Pascual and Marc A. Rosen

Received: 30 March 2021

Accepted: 29 April 2021

Published: 30 April 2021

Publisher's Note: MDPI stays neutral with regard to jurisdictional claims in published maps and institutional affiliations.
Department of Business Administration, College of Management and Economics, Dongguk University, Gyeongju 38066, Korea; yklee2329@dongguk.ac.kr; Tel.: +82-54-770-2329; Fax: +82-54-770-2469

\begin{abstract}
The role of digital technostress and self-efficacy in digital marketing research is seldom discussed and even more rarely examined among Gen $Z$ consumers. This study investigates the relationships between four sub-dimensions of technostress (complexity, overload, invasion, and uncertainty), digital technology self-efficacy, and fintech usage intention. Data from a total of 266 Chinese Gen $Z$ consumers were used in multiple regression analysis. The results of the study generally support that all sub-dimensions of technostress were negatively related to fintech usage intention. Related to the moderating effects of digital technology self-efficacy on the relationship between the four sub-dimensions of technostress and fintech usage intention, significant interaction effects with complexity and overload were found. Finally, the study discusses the theoretical and managerial implications of the research findings.
\end{abstract}

Keywords: digital technostress; digital techno self-efficacy; fintech usage intention; Chinese Gen $\mathrm{Z}$ consumers

\section{Introduction}

"Fintech" is a portmanteau formed from the terms finance and technology [1]. It is currently utilized in nearly every consumer financial service-from mobile payment to online investment management service, consumer insurance, and peer-to-peer lending [2]. Fintech is rapidly revolutionizing the financial landscape with the progress of the fourth industrial revolution [3,4]. In particular, the Chinese fintech industry has evolved at a remarkable pace at which the rest of the world struggles to emulate [5-7]. Leading Chinese fintech businesses, such as mobile payment services and big data-based online lending, are at the frontier of the global fintech industry [8]. The Chinese fintech industry has evolved differently from those in developed countries in many ways. While Western countries have mainly developed fintech that focuses on cryptocurrencies or cross-border payment services, Chinese fintech businesses have focused more on consumer mobile financial services, such as mobile payment and online lending $[9,10]$. Therefore, for Chinese consumers, fintech is becoming a most widely used digital technology that encompasses most onlineto-offline $(\mathrm{O} 2 \mathrm{O})$ commerce from mobile payment to entertainment, education, cultural services, transportation, medical care, and other miscellaneous consumption areas [11]. Therefore, many digital marketing researchers have tried to find determinants of consumers fintech behavior in China as fintech has most vastly reached Chinese consumers. Zhou identified that trust, flow, and satisfaction determine the continuance intention of mobile payment [12]. Chuang et al. found that brand and service trust, perceived usefulness, and perceived ease of use positively related to the adoption of fintech service [13]. Wang et al. found that trust in fintech service and structural assurance can encourage the continuance usage intention of fintech service [14]. While many researchers identified the promoting factors of fintech behavior in digital marketing literature, few studies have focused on the constraints of fintech behavior. 
Digital innovations, such as fintech, offer greater convenience and efficiency to consumers, but some consumers experience digital technostress due to the rapid development of digital technology. In this digital revolution era, consumers feel the pressure to quickly adapt to a new digital technology as soon as they have adapted to the previous one. In addition, as the fintech industry evolves, risk of personal privacy infringement, financial accidents, and fraud increase, and these risks are likely to increase consumers' technostress. Technostress has early been defined as a modern disease of adaptation caused by an inability to cope with new computer technologies in a healthy manner [15]. Moreover, it has recently been defined as a physical, behavioral, and psychological strain resulting from information and communication technology (ICT)-driven changes in work environment. Many researchers have examined the impacts of technostress on organizational and personal performances at work because technostress construct was developed in the human resource management research field. However, the impact of technostress on digital technology adoption behavior from the consumers' perspective has hardly been examined. Moreover, research focusing on the technostress of Gen Z consumers-the so-called digital natives [16] - is even more scarce. Therefore, the study tries to empirically examine the relationship between digital technostress and fintech usage behavior among Chinese Gen $\mathrm{Z}$ consumers, who most commonly use fintech services in their daily life [16]. In addition, the study tries to verify the moderating effect of digital technology self-efficacy on the relationship between digital technostress and fintech usage behavior among Gen $Z$ consumers. Gen Z consumers are called "digital natives" who have grown up in the digital age and so are likely to have high digital technology self-efficacy; however, they also experience technostress caused by rapidly changing digital technologies. Therefore, the study aims to find a sustainable fintech marketing strategy in the Chinese Gen Z consumer market, which is the most rapidly emerging in the world, through finding new empirical evidence of an interaction effect between technostress and digital technology self-efficacy on fintech usage intention of Gen $\mathrm{Z}$ consumers.

The study is expected to expand the scope of digital marketing research by examining the impact of technostress on fintech usage behavior of Gen $Z$ consumers which, unlike technostress, has been mainly researched in terms of work and mental health. For the digital marketing research field, discovering constraint factors of consumer's usage behavior of new digital technology, such as fintech, is as important as finding promoting factors as new digital technologies are expected to be continuously developed and be more widely adopted to a variety of products and services. Digital marketers should find and manage the impediments of fintech usage behavior of Gen $\mathrm{Z}$ consumers, which form the most important market segment for digital company. Therefore, the study results are expected to provide practical and academic implications for the digital marketing field.

\section{Literature Review and Hypotheses}

\subsection{Fintech Growth in China}

Fintech is being used in various consumer financial services, from mobile payment to lending, stocks, insurance, remittances, and asset management. Mobile payment is the most widely used fintech service in China. It was first used in earnest for internet and mobile payment services to support e-commerce consumers in the early 2000s [17]. As of 2019, 87\% of Chinese consumers were using fintech services, far ahead of Hong Kong, Singapore, South Korea (67\%), and Australia (58\%) [17]. Alipay and WeChat Pay, which are non-bank mobile payment business, experienced 75\% annual growth between 2015 and 2019. The Chinese mobile payment business has grown in such a way that non-bank companies' mobile payment services dominate banks' mobile banking payment services [18,19]. Tencent, Alibaba, and other major tech firms have been changing the financial services landscape. The mobile payment platform is creating a variety of innovative business models both online and offline, beyond the provision of payment services [20]. The rapid growth of mobile payments by non-bank payment companies in early 2000 resulted in online shopping being quickly replaced by mobile shopping as the Chinese communication 
system rapidly jumped from wired communication to wireless communication. The online payment system of Chinese banks was insufficient at that time; thus, the payment system of non-bank internet e-commerce companies, such as Alibaba, could develop significantly. Alipay currently provides total consumer financial services that support various financial activities beyond mobile payment services, including personal asset management, online insurance, loans, and stock trading [19]. In addition, fintech is becoming the digital technology most used in China in various daily consumption activities, such as cultural content, education, medical care, beauty, and housekeeping as well as financial services.

However, fintech has also created serious financial risks and social problems in China. The fintech sector is still in its early stage of development, and many fintech business models are not holistically developed. Chinese authorities are currently trying to formulate new financial regulations for balancing between innovation and stability. However, despite these efforts by the Chinese authorities, the development of fintech exposes consumers to the risk of hacking, ransomware, and financial fraud caused by personal information leakage [10]. Recently, peer-to-peer (P2P) financial transaction accidents have frequently occurred in China, recording millions of victims due to the insolvency of P2P financial companies [8]. Chinese authorities are strengthening the supervision and regulation of the fintech industry as the number of accidents of online payment and P2P lending as well as consumer concerns about financial risks have recently increased [21]. In 2019, CNNIC conducted a survey regarding the problems of most concern when using online services in which 30,000 internet users in 31 regions of China participated. As a result, respondents expressed concern in the order of personal information leakage $(20.4 \%)$, online transaction fraud $(17.0 \%)$, hacking or virus infection $(10.7 \%)$, and account or password theft $(9.9 \%)$ [11].

\subsection{Digital Technostress}

Stress refers to a state in which negative emotions appear in the process of responding to external threats, a physiological imbalance is felt, and involving reacting to survive [22]. In the medical field, researchers have mainly paid attention to the patients' psychological and physiological reactions and the negative effects of stress on the body [23]. Further, the academic fields of sociology, psychology, and business have also begun to pay attention to the effects of stress as the complexity of modern society and the psychological burden of people increased. In particular, many researchers in the human resource management field have paid much attention to the impact of employee job stress on organizational activities and performance [24-29]. In addition, job stress research began to focus on technical stress related to computer or internet use with the rapid development of ICT [15]. Technical stress is addressed in various terms, such as Technostress, Computer Anxiety, Negative Computer Attitudes, Computer Stress, Technophobia, Computerphobia, and Cyberphobia. Technostress is a compound word first used in 1982 by the American clinical psychologist Craig Brod, who defined it as a modern disease of adaptation caused by the inability to cope with the new computer technologies in a healthy manner [15]. Hudiburg also defined technostress as an adaptation-related modern disease resulting from the inability to cope with new technologies used in digital devices, such as computers [30]. Shu and Wang found that technostress is positively related to computer literacy and the acceptance of digital technologies [31]. Moreover, Arnetz and Wiholm found that employees who were heavily dependent on computers for their work were usually observed to be in a state of technostress arousal [32].

The existing technostress literature presents technostress as being multi-dimensional, including work overload, invasion of individual life, high complexity of technology, and occupational crisis $[15,33]$. Salanova et al. and Tarafdar et al. also insisted that technostress consists in the sub-dimensions of technology overload, invasion, complexity, insecurity, and uncertainty $[34,35]$. Tarafdar et al. developed the technostress measurement scale and validated the construct in the US [35]. The scale consists of five sub-dimensions of technostress that computer technology users can potentially experience at work. First, techno-overload is the stress that emerges when ICTs push employees to work faster. 
Second, techno-invasion is the stress that emerges when pervasive ICTs invade personal life. Third, techno-complexity is the stress that emerges when the complexity of new ICTs makes employees feel incompetent. Fourth, techno-insecurity is the stress that emerged when fast-changing ICTs threaten the job security of employees. Finally, techno-uncertainty is the stress that is imposed on employees due to the constant changes, upgrades, and bug fixes in ICT hardware and software. Brillhart insisted that technostress consists of four sub-dimensions of data smog, multitasking madness, computer hassles, and burn-out [36]. Ayyagari et al. argued that technostress consists of five sub-dimensions, namely workhome conflict, work overload, invasion of privacy, role ambiguity, and job insecurity, and that they are related to users' perception of ICT's usefulness, complexity, trust, connectivity, anonymity, and development speed [37]. The sub-dimensions of technostress presented in previous research on technostress are shown in Table 1.

Table 1. Sub-dimensions of technostress.

\begin{tabular}{ccc}
\hline Researcher & Sub-Dimensions & Number \\
\hline Brod [15] & $\begin{array}{c}\text { work overload, invasion of individual life, high } \\
\text { complexity of technology, occupational crisis }\end{array}$ & 4 \\
\hline Brillhart [36] & $\begin{array}{c}\text { data smog, multitasking madness, } \\
\text { computer hassles, burn-out }\end{array}$ & 5 \\
\hline Tarafdar et al. [35] & $\begin{array}{c}\text { overload, invasion, } \\
\text { complexity, insecurity, uncertainty }\end{array}$ & 4 \\
\hline Ragu-Nathan et al. [38] & $\begin{array}{c}\text { techno-overload, techno-complexity, } \\
\text { techno-anxiety, techno-uncertainty }\end{array}$ \\
\hline Ayyagari et al. [37] & $\begin{array}{c}\text { work-home conflict, work overload, invasion of } \\
\text { privacy, role ambiguity, job insecurity }\end{array}$ & 5 \\
\hline
\end{tabular}

Technostress has been examined by digital marketing researchers since ICT began to widely invade general consumers' daily life [36]. Lee and Lee argued that some digital device users tend to stop using digital devices, such as digital breaks or digital detox, to avoid stress, which appears as a side effect of using smart devices [39]. Çoklar and Şahin examined the technostress levels of Turkish social networking services (SNS) users to find that they have a "medium technostress level" [40]. They found that technostress results from the pressure of using technology, remembering large quantities of passwords and usernames, and anxiety regarding data loss [41]. Chen et al. conceptualized technostress as a phenomenon of end users experiencing overload and intrusiveness due to too much information and communication in a short period of time when they use mobile shopping applications [41]. Perceived information overload is referred to as a kind of mental stress when people perceive the environment as a condition exceeding their ability to deal with [42]. According to the stressor-strain-outcome framework, perceived overload induces fatigue and dissatisfaction in the SNS environment, which further increase the discontinuance intentions of SNS users [43]. In addition, perceived intrusiveness lowers the chances of accepting and allowing permission marketing [44]. It was also determined that the social, hedonic, and cognitive uses of social media induce technostress and SNS exhaustion which, in turn, influence a discontinuous use intention based on the stimulusorganism-response framework [45].

New digital technology, such as fintech, provides consumers with convenience and new customer experiences, but it also induces technostress, such as pressure to adapt to new technologies and risks from technological imperfections. Consumers experience technostress while utilizing fintech services, but few studies have verified the impact of technostress from the perspective of fintech users. It is harder to find research on technostress among Gen $Z$ consumers who are always involved in various services and products adopting fintech. Even young and educated consumers are likely to feel difficulty in constantly acquiring new digital technology as this rapidly changes from day to day. In 
addition to the pressure of acquiring new digital technology that is constantly updated, there are many other types of technostress, such as privacy invasion problems, digital security instability, difficulties in using complex digital devices, and pressure to replace new digital devices due to the continual updates to digital technology. Therefore, the study assumes that consumers' digital technostress negatively affects the usage intention of fintech services based on previous related research. In detail, the study assumes that four sub-dimensions of technostress - complexity, overload, invasion, and uncertainty-are negatively related to usage intention of fintech services [35,38]. Meanwhile, the study excluded insecurity (or job insecurity) as a sub-dimension of technostress which might affect fintech usage intention. Tarafdar et al. and Ayyagari et al. explained that insecurity is a stress that emerged when fast-changing ICTs threaten the job security of employees $[35,37]$. Therefore, insecurity is not likely to be related with the stress that Gen $\mathrm{Z}$ consumers feel when using fintech service. Therefore, hypotheses 1 to 4 are presented as follows:

Hypothesis 1. Digital techno-complexity is negatively related to the usage intention of fintech services.

Hypothesis 2. Digital techno-overload is negatively related to the usage intention of fintech services.

Hypothesis 3. Digital techno-invasion is negatively related to the usage intention of fintech services.

Hypothesis 4. Digital techno-uncertainty is negatively related to the usage intention of fintech services.

\subsection{Digital Technology Self-Efficacy}

Bandura defined self-efficacy as people's judgment of their capabilities to organize and execute courses of action required to attain designated types of performances [46]. Self-efficacy is a strong sense of personal efficacy related to better health, higher achievement, and more social integration, and it represents the key construct in social cognitive theory [46-48]. Bagozzi defined self-efficacy as an individual's confidence in their own work ability. Self-efficacy has received much attention in the business literature [49]. Gist and Mitchell found that people who think they can perform their task well show better work performance than those who think that they will fail [50]. In the organizational behavior research field, researchers found that self-efficacy is positively related to job proficiency and performance, and self-efficacy lowers the negative impact of job stress on job performance [51-53].

Meanwhile, as ICT invades every corner of people's life, such as work, school, and daily lives, technology self-efficacy is attracting much attention in many research disciplines, such as psychology, education, and business. Cassidy and Eachus presented computer user self-efficacy as a factor that contributes to success in tasks in the domain of computer technology [54]. They further adapted to cover digital self-efficacy to measure individual self-efficacy in the digital domain. Self-efficacy-related ICT is often used in terms of computer efficacy or internet efficacy [55]. Venkatesh and Davis defined computer selfefficacy as a self-assessment of one's ability to use information technology or one's belief that people can use computer or internet-related technologies well [56]. Compeau and Higgins defined computer self-efficacy as a self-judgment of one's ability to use information technology [57]. Rogers found that technology self-efficacy is a trait that is variable at an individual level and positively influences the acceptance of new technologies, and that technology self-efficacy has a positive relationship with the innovation and acceptance of new technologies of organizational leaders [58]. Table 2 summarizes the antecedents and outcome variables of technological self-efficacy used in previous studies related to technological self-efficacy. Meanwhile, many researchers pay much attention to the impact of consumers' technology self-efficacy on the acceptance behavior of ICT products or services since ICT began to be widely used for general consumers. According to Bandura's theory, people with high self-efficacy tend to believe they can perform well even if they are in difficult situations, and tend to view difficult tasks as something to be mastered rather than something to be avoided [48]. Therefore, people with high self-efficacy are 
likely to put more effort into learning technological skills, while those with low technology self-efficacy are likely to put in relatively little effort or give up halfway. In addition, people with high technology self-efficacy find using new technology relatively to be less difficult and show a positive attitude toward using technology [58]. The study therefore assumes that digital technology self-efficacy positively affects the usage intention of fintech services and presents the following hypothesis 5:

Hypothesis 5. Digital technology self-efficacy is positively related to the usage intention of fintech services.

Perceived self-efficacy to control thought processes is a key factor in regulating stress and depression [46]. People with high self-efficacy tend to approach threatening situations with the assurance that they can have control over situations, and their efficacious thought reduces stress and lowers vulnerability to depression [46]. A significant amount of research has shown that self-efficacy acts to decrease people's potential for negative stress by increasing their belief of being in control of the threatening situations they encounter. The perception of being in control represents an important buffer of negative stress [59]. $\mathrm{Lu}$ et al. found that managerial self-efficacy had significant moderating effects on the stressor-strain relationship in the Chinese workplace [60]. Self-efficacy was also found to be a stress moderator in some of the stressor-work well-being relationships among employees in Hong Kong and Beijing. Some researchers have found that mobile users with high self-efficacy prefer to take more proactive behavior to deal with stressors of mobile shopping apps [41]. Although little research has tried to examine the relationship between digital technology self-efficacy, technostress, and new digital technologies' usage intention from the consumer perspective, many researchers in clinical, educational, social, business management, health, and personality psychology disciplines have found that self-efficacy lowers the negative effects of stress. People with high self-efficacy can accurately perceive their situation and self-manage themselves in stressful situations; thus, self-efficacy is positively related with an active lifestyle. Therefore, technology self-efficacy is likely to lower the negative effects resulting from people's psychological anxiety or stress caused by new digital technology. Based on previous research arguments, the study presents the following hypotheses 6 to 9:

Hypothesis 6. Digital technology self-efficacy lowers the negative impact of digital technocomplexity on the usage intention of fintech services.

Hypothesis 7. Digital technology self-efficacy lowers the negative impact of digital techno-overload on the usage intention of fintech services.

Hypothesis 8. Digital technology self-efficacy lowers the negative impact of digital techno-invasion on the usage intention of fintech services.

Hypothesis 9. Digital technology self-efficacy lowers the negative impact of digital technouncertainty on the usage intention of fintech services.

\section{Research Model and Methodology}

\subsection{Research Model}

The research model is developed based on the assumption that the four dimensions of technostress (complexity, overload, invasion, and uncertainty) resulting from rapidly changing digital technology are negatively related to fintech usage intention. Constructs rooted in the secondary evaluation procedure (digital technology self-efficacy) are also considered as determinants to fintech usage intention. In addition, it is also argued that digital technology self-efficacy moderates the relationship between technostress and fintech usage intention. For the convenience of notation, the study will use abbreviations of the constructs in the latter part of this paper. Figure 1 illustrates the research model. 


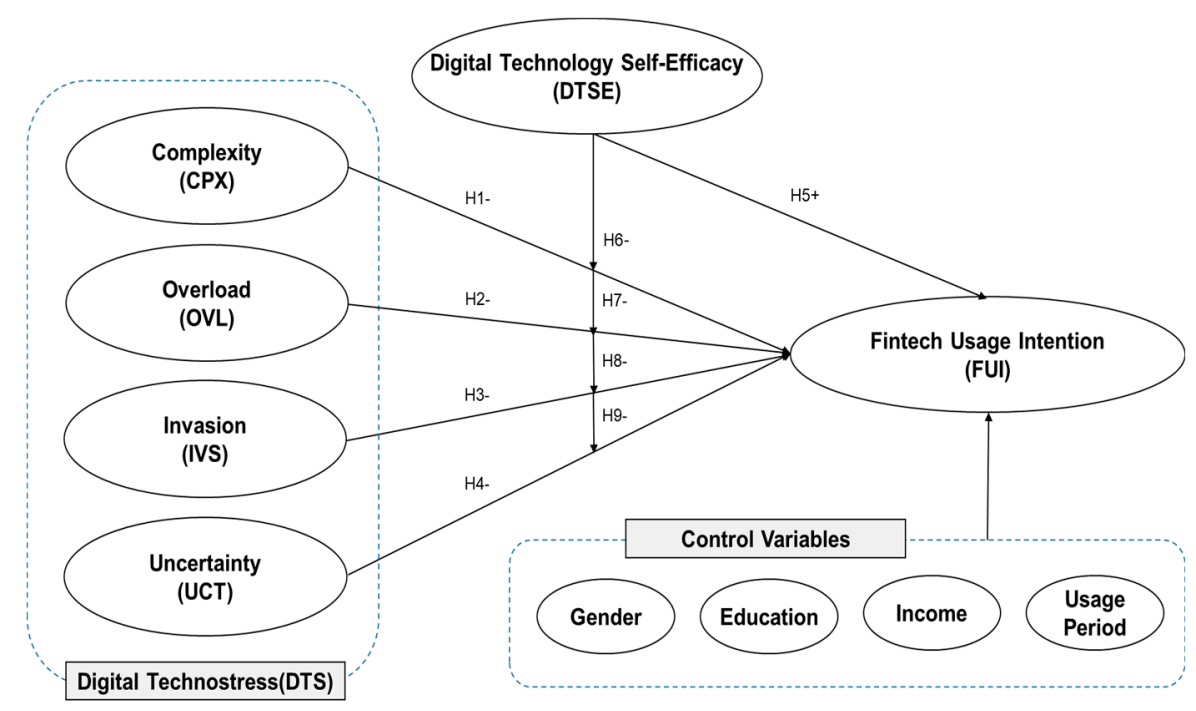

Figure 1. Conceptual research model.

\subsection{Data Collection and Sampling}

The study collected data by means of an online survey administered by Wenjuan Xing (www.wjx.cn, accessed on 18 September 2020), which is a professional online survey website in China. A pilot test was conducted in July 2020 for 30 Chinese undergraduate students at D university in Korea that did not form part of the sampling frame of the main study, so as to assert the reliability of the scales used the questionnaire [61,62]. The feedback resulted from a pilot test was used to refine a final questionnaire. Data collection used a snowball sampling method in August to September 2020 in which the online survey URL was transmitted to the respondents who had previously agreed to receive it. The study collected a total of 314 responses from the participants. It excluded samples with a less than $20 \%$ response rate of all measurement items or missing responses to the outcome variable to ensure the external validity of the data, in addition to considering the subject scope. The study used 266 samples for the final analysis.

Table 2 provides demographic information on the sample. The number of male respondents, at $53.4 \%$, was slightly higher than that of females at $46.6 \%$. Of the respondents, $94.7 \%$ of participants were single, and $5.3 \%$ were married. More than $80 \%$ had bachelor's degrees and higher, and around $70 \%$ respondents had an average monthly personal income under CNY 2000. Furthermore, $70.7 \%$ of the respondents answered that they had used a smartphone for over five years.

\subsection{Construct Measurement}

The construct measurement scale employed in the study was taken from existing literature, and all constructs dealing with perceptions were measured using five-point Likert scales $(1=$ strongly disagree and $5=$ strongly agree $)$. The operational definition and measurement scale for constructs are as follows. The study first defined digital technostress (DTS) as a psychological pressure consumers feel from using digital technology and digital devices. The study modified the technostress measurement scale of Tarafdar et al. based on the scope and purpose of the study and used the modified measurement scale to measure the sub-dimensions of technostress: CPX, OVL, IVS, and UCT [35]. The study measured CPX as four items, OVL as four items, IVS as three items, and UCT as two items, as shown in Table 3. Next, the study defined digital technology self-efficacy (DTSE) as a psychological self-belief that people can utilize digital technology well, and developed three measurement items based on the measurement scale of Cassidy and Eachus [54]. Finally, the study defined FUI as a consumer's intention to choose and use fintech services as much as possible and developed a measurement scale for FUI based on the technology acceptance model (TAM) [63]. The full survey instrument is presented in Table 3. 
Table 2. Demographic information of respondents.

\begin{tabular}{cccc}
\hline \multicolumn{1}{c}{ Attribute Structure of Sample } & Frequency & Percentage (\%) \\
\hline \multirow{2}{*}{ Gender } & Male & 142 & 53.4 \\
& Female & 124 & 46.6 \\
\hline \multirow{2}{*}{ Marriage status } & Single & 252 & 94.7 \\
& Married & 14 & 5.3 \\
\hline \multirow{2}{*}{ Educational background } & Middle school & 13 & 4.9 \\
& High school & 27 & 10.2 \\
& Undergraduate school & 186 & 69.9 \\
& Graduate school or above & 40 & 15.1 \\
\hline \multirow{3}{*}{ Monthly personal income } & Under 500 yuan & 65 & 24.4 \\
& 501-1000 yuan & 80 & 30.1 \\
& 1001-2000 yuan & 43 & 16.2 \\
& 2001-3000 yuan & 22 & 8.3 \\
& 3001-5000 yuan & 17 & 6.4 \\
& Above 5000 yuan & 39 & 14.7 \\
\hline \multirow{3}{*}{ Usage period of smart phone } & Less than 1 year & 7 & 2.6 \\
& $1-3$ years & 27 & 10.2 \\
& 3-5 years & 44 & 16.5 \\
& 5-7 years & 67 & 25.2 \\
& L-9 years & 57 & 21.4 \\
& Longer than 9 years & 64 & 24.1 \\
\hline
\end{tabular}

Table 3. Constructs and measurement items.

\begin{tabular}{|c|c|c|}
\hline Constructs & Measurement Items & Sources \\
\hline \multirow{4}{*}{ CPX } & I do not know enough about digital technology to handle my job satisfactorily. & \multirow{13}{*}[35,64]{} \\
\hline & I need a long time to understand and use new digital technologies. & \\
\hline & I do not find enough time to study and upgrade my digital technology skills. & \\
\hline & I often find it too complex for me to understand and use new digital technologies. & \\
\hline \multirow{4}{*}{ OVL } & I am forced by digital technology to do more work than I can handle. & \\
\hline & I am forced by digital technology to know even unnecessary information. & \\
\hline & I am forced by digital technology to work much faster. & \\
\hline & I am forced by digital technology to work with very tight time schedules. & \\
\hline \multirow{3}{*}{ IVS } & I feel my personal life is being invaded by digital technology. & \\
\hline & I spend less time with my family due to this technology. & \\
\hline & I sacrifice my personal time to keep up with new technologies. & \\
\hline \multirow{2}{*}{$\mathrm{UCT}$} & I think there are always new developments in digital technologies. & \\
\hline & I think there are constant changes in computer and mobile software. & \\
\hline \multirow{3}{*}{ DTSE } & I believe I can handle most digital technology well. & \multirow{3}{*}{ [54] } \\
\hline & Most digital technologies I have had experience with have been easy to use. & \\
\hline & Digital technology helps me to save a lot of time. & \\
\hline \multirow{4}{*}{ FUI } & I love to choose financial services that adapt fintech. & \multirow{4}{*}[63]{} \\
\hline & I want to use the fintech services as much as possible. & \\
\hline & $\begin{array}{l}\text { I prefer fintech payment methods over other payment methods, such as credit card, cash } \\
\text { payment, or bank transfer, etc. }\end{array}$ & \\
\hline & I would recommend fintech services to my friends if I had the chance. & \\
\hline
\end{tabular}




\subsection{Research Methodology}

The data analysis methods used in the study are as follows. First, frequency analysis was conducted to investigate the demographic characteristics of respondents. Second, the feasibility and reliability tests of the measurement scale were conducted to examine the predictability and accuracy of constructs. Third, correlation analysis was conducted to examine the correlations among constructs. Fourth, moderated regression analysis (MRA) was conducted to examine the relationships between constructs using IBM SPSS 20.0. MRA is an analytic approach that maintains the integrity of a sample yet provides a basis for controlling the effects of a moderator variable; therefore, MRA can avoid the loss of information resulting from an artificial transformation of a continuous variable into a qualitative one [65]. The study adopts the MRA to build three regression Equations as follows, and it examines the equality of the regression coefficients for the following three regression equations:

$$
\begin{gathered}
Y=a+b_{1} X_{1}+b_{2} X_{2}+b_{3} X_{3}+b_{4} X_{4} \\
Y=a+b_{1} X_{1}+b_{2} X_{2}+b_{3} X_{3}+b_{4} X_{4}+b_{5} Z \\
Y=a+b_{1} X_{1}+b_{2} X_{2}+b_{3} X_{3}+b_{4} X_{4}+b_{5} Z+b_{6} X_{1} Z+b_{7} X_{2} Z+b_{8} X_{3} Z+b_{9} X_{4} Z
\end{gathered}
$$

In the above equations, if (2) and (3) are not significantly different, then $Z$ is not a moderating variable but a simple independent variable. If Equations (1) and (2) are not different from each other but different from Equation (3), then $\mathrm{Z}$ is a pure moderating variable. Lastly, if Equations (1)-(3) are not different from each other, then $Z$ is a quasimoderating variable. The study adopts the above moderated regression analysis approach to identify the research model.

\section{Empirical Analysis and Results}

\subsection{Validity and Reliability of Measurement Instruments}

The study first assessed the validity and reliability of the measurement model. An exploratory factor analysis was conducted on the 19 items relating to variables. Six principal component factors were extracted, as they had a cut-off factor loading of 0.6 and an eigenvalue greater than 1 [66]. Of the total variances, CPX accounted for $19.44 \%$, OVL accounted for $12.97 \%$, IVS accounted for $12.41 \%$, UCT accounted for $8.29 \%$, DTSE accounted for $23.89 \%$, and FUI accounted for $19.44 \%$. The six factors accounted for $84.79 \%$ of the total variability. The rotated component matrix of the factor analysis is shown in Table 4 . Regarding the construct reliability of the six factors, all values for Cronbach's $\alpha$ exceeded the threshold value of 0.7. This provides sufficient evidence for the high reliability of constructs listed above [67]. The detailed results of the validity and reliability analysis are shown in Table 4.

\subsection{Correlation Test}

Table 5 shows the correlation matrix between the constructs. This study used partial correlation to measure nonlinear as well as linear relationships between variables. Most variables show a relatively low correlation of less than 0.6 , which demonstrates that there is little chance for multicollinearity to exist between the constructs. The relationships between variables in the correlation matrix are consistent with the direction of the hypotheses. In addition, although the constructs show low Pearson correlation coefficients, nonlinear relationships between them may still exist [68]. 
Table 4. Measurement item's loading $(\lambda)$ and construct's convergent validity.

\begin{tabular}{ccccccc}
\hline Measurement Items & CPX & OVL & IVS & UCT & DTSE & FUI \\
\hline CPX1 & $\mathbf{0 . 9 0 4}$ & 0.146 & 0.199 & 0.058 & -0.018 & 0.014 \\
CPX 2 & $\mathbf{0 . 9 0 7}$ & 0.089 & 0.219 & -0.006 & 0.013 & -0.033 \\
CPX 3 & $\mathbf{0 . 8 9 1}$ & 0.081 & 0.216 & 0.061 & -0.033 & -0.023 \\
CPX 4 & $\mathbf{0 . 8 9 5}$ & 0.065 & 0.210 & 0.064 & -0.078 & -0.046 \\
OVL1 & 0.084 & $\mathbf{0 . 7 4 4}$ & 0.176 & 0.336 & 0.165 & 0.229 \\
OVL 2 & 0.241 & $\mathbf{0 . 8 1 4}$ & 0.237 & 0.057 & 0.204 & -0.029 \\
OVL 3 & 0.087 & $\mathbf{0 . 7 9 7}$ & 0.187 & 0.307 & 0.144 & 0.188 \\
IVS 1 & 0.296 & 0.216 & $\mathbf{0 . 8 1 1}$ & 0.199 & 0.013 & 0.012 \\
IVS 2 & 0.330 & 0.228 & $\mathbf{0 . 8 2 2}$ & 0.025 & 0.094 & -0.022 \\
IVS 3 & 0.282 & 0.127 & $\mathbf{0 . 8 7 1}$ & 0.078 & 0.021 & -0.017 \\
UCT1 & 0.217 & 0.365 & 0.209 & $\mathbf{0 . 7 5 7}$ & 0.176 & 0.076 \\
UCT 2 & -0.018 & 0.293 & 0.084 & $\mathbf{0 . 7 6 5}$ & 0.303 & 0.247 \\
DTSE1 & -0.060 & 0.186 & 0.007 & 0.128 & $\mathbf{0 . 8 4 0}$ & 0.306 \\
DTSE2 & -0.011 & 0.079 & 0.007 & 0.074 & $\mathbf{0 . 8 5 6}$ & 0.323 \\
DTSE3 & -0.057 & 0.250 & 0.127 & 0.294 & $\mathbf{0 . 7 0 7}$ & 0.206 \\
FUI1 & -0.038 & 0.076 & 0.020 & 0.150 & 0.197 & $\mathbf{0 . 9 0 2}$ \\
FUI2 & -0.075 & 0.112 & 0.014 & 0.114 & 0.166 & $\mathbf{0 . 9 2 7}$ \\
FUI3 & 0.004 & 0.085 & -0.001 & 0.077 & 0.210 & $\mathbf{0 . 9 0 6}$ \\
FUI4 & 0.018 & 0.063 & -0.054 & 0.000 & 0.218 & $\mathbf{0 . 8 9 4}$ \\
Cronbach's $\alpha$ & $\mathbf{0 . 9 4 6}$ & $\mathbf{0 . 8 6 1}$ & $\mathbf{0 . 9 0 4}$ & $\mathbf{0 . 7 8 0}$ & $\mathbf{0 . 8 6 3}$ & $\mathbf{0 . 9 4 7}$ \\
Eigenvalue & 3.646 & 2.464 & 2.459 & 1.576 & 2.327 & 3.693 \\
Variance Explained $(\%)$ & 19.44 & 12.97 & 12.41 & 8.29 & 12.25 & 19.43
\end{tabular}

CPX: complexity; OVL: overload; IVS: invasion; UCT: uncertainty; DTSE: digital technology self-efficacy; FUI: fintech usage intention.

Table 5. Correlations between constructs $(n=266)$.

\begin{tabular}{|c|c|c|c|c|c|c|c|c|c|c|}
\hline Variables & gen. & edu. & inc. & sup. & CPX & OVL & IVS & UCT & DTSE & FUI \\
\hline gen. & 1 & & & & & & & & & \\
\hline edu. & $0.185^{* *}$ & 1 & & & & & & & & \\
\hline inc. & $-0.140 *$ & 0.091 & 1 & & & & & & & \\
\hline sup. & -0.075 & $0.224 * *$ & $0.306^{* *}$ & 1 & & & & & & \\
\hline CPX & -0.087 & -0.063 & -0.069 & -0.078 & 1 & & & & & \\
\hline OVL & -0.025 & $0.162 * *$ & 0.017 & $0.185^{* *}$ & $0.295^{* *}$ & 1 & & & & \\
\hline IVS & -0.074 & 0.098 & 0.057 & 0.027 & $0.551^{* *}$ & $0.480^{* *}$ & 1 & & & \\
\hline UCT & 0.047 & $0.176^{* *}$ & -0.060 & $0.140 *$ & $0.201^{* *}$ & $0.573^{* *}$ & $0.363^{* *}$ & 1 & & \\
\hline DTSE & 0.007 & 0.123 * & 0.014 & $0.131 *$ & -0.049 & $0.450 * *$ & $0.143^{* *}$ & $0.513^{* *}$ & 1 & \\
\hline FUI & -0.036 & $0.140 *$ & 0.039 & 0.053 & -0.042 & $0.284^{* *}$ & 0.016 & $0.338^{* *}$ & $0.531^{* *}$ & 1 \\
\hline
\end{tabular}

Note: ${ }^{*} p<0.05,{ }^{* *} p<0.01$. gen.: gender; edu.: education; inc.: income; sup.: smartphone usage period; CPX: complexity; OVL: overload; IVS: invasion; UCT: uncertainty; DTSE: digital technology self-efficacy; FUI: fintech usage intention.

\subsection{Hypotheses Test}

This study conducted a hierarchical regression analysis to find more detailed causal relationships among variables. First, the study set gender, education, income, and smartphone usage period as control variables; it then verified the influences of the control variables on FUI in Model 1. The results found that the $F$ value was 1.594 , and $\mathrm{R}^{2}$ was 0.024; therefore, Model 1 was not statistically significant. Next, in Model 2, regression analysis was conducted on the impacts of the control variables and four sub-dimensions of technostress (CPX, OVL, IVS, and UCT) on FUI. The results found that the $F$ value was 6.225 , and $\mathrm{R}^{2}$ was 0.163 ; therefore, Model 2 was statistically significant. In detail, Model 2 demonstrated that OVL, IVS, and UCT negatively affect FUI $(\beta=-0.177, p<0.05$; $\beta=-0.151, p<0.05 ; \beta=-0.228, p<0.01)$. In Model 3 , regression analysis was conducted to analyze the impacts of control variables, four sub-dimensions of technostress (CPX, OVL, IVS, and UCT), and DTSE on FUI. The results found that the $F$ value was 12.996 , and $\mathrm{R}^{2}$ was 0.314; therefore, Model 3 was statistically significant. Model 3 demonstrated that IVS has a significant negative impact of on FUI $(\beta=-0.133, p<0.05)$, and DTSE has a significant 
positive impact on FUI $(\beta=0.470, p<0.01)$. Finally, in Model 4 , regression analysis was conducted to examine the impacts of control variables, four sub-dimensions of technostress (CPX, OVL, IVS, and UCT), DTSE, and the four interaction variables $(\mathrm{CPX} \times \mathrm{DTSE}$, OVL $\times$ DTSE, IVS $\times$ DTSE, and UCT $\times$ DTSE) on FUI. The results found that the $F$ value was 12.110 , and $\mathrm{R}^{2}$ was 0.385 ; therefore, Model 4 was statistically significant. Model 4 demonstrated that the four control variables have no significant impacts on FUI. The four sub-dimensions of technostress (CPX, OVL, IVS, and UCT) are all negatively related to FUI $(\beta=-0.615, p<0.05 ; \beta=-0.800, p<0.01 ; \beta=-0.544, p<0.01 ; \beta=-0.420, p<0.05)$, while DTSE has a significant positive impact on FUI $(\beta=0.661, p<0.01)$. Of the interaction variables, the results showed that CPX $\times$ DTSE and OVL $\times$ DTSE interactions have significant negative impacts on FUI $(\beta=-0.357, p<0.05 ; \beta=-0.498, p<0.05)$. In addition, impacts of CPX $\times$ DTSE and OVL $\times$ DTSE interactions on FUI $(\beta=-0.357, p<0.05 ; \beta=-0.498$, $p<0.05)$ were lower than the direct impacts of CPX and OVL on FUI $(\beta=-0.615, p<0.05$; $\beta=-0.800, p<0.01)$ in Model 4. In result, DTSE lower the negative impacts of CPX and OVL on FUI.

Meanwhile, the study verified the statistical significance of direct and moderating effects of variables by comparing the regression coefficients of each model [65]. As a result of estimating the analysis model of the study with the regression Equations of Model 2 and 3, the explanatory power of Model 3 increased at a statistically significant level in comparison with Model $2\left(\triangle F=20.81^{* *}\right)$. In addition, the explanatory power of Model 4 increased at a statistically significant level $\left(\triangle F=3.73^{* *}\right)$ in the comparison of the explanatory power of Model 3 and Model $4[65,69,70]$. Therefore, the study finally interpreted the research results based on Model 4. In Model 4, the four sub-dimensions of technostress (CPX, OVL, IVS, and UCT) all negatively affect FUI; thus, H1 to H4 are supported. In addition, DTSE has a positive impact on FUI; hence, H5 is supported. Finally, of the interaction variables, the results of Model 4 showed that CPX $\times$ DTSE and OVL $\times$ DTSE interactions have significant negative impacts on FUI; therefore, H6 and H7 are supported. The detailed analysis results are shown in Table 6 below.

Table 6. Results of multiple regression analysis (MRA).

\begin{tabular}{|c|c|c|c|c|c|}
\hline \multirow{3}{*}{ Variables } & & \multicolumn{4}{|c|}{ (Dependent variable) Fintech Usage Intention } \\
\hline & & \multicolumn{4}{|c|}{$N=266$} \\
\hline & & Model 1 & Model 2 & Model 3 & Model 4 \\
\hline \multirow{4}{*}{ Control variables } & Gender. & -0.060 & -0.077 & -0.079 & -0.088 \\
\hline & Education & $0.147^{* *}$ & 0.094 & 0.099 & 0.096 \\
\hline & Income & 0.014 & 0.058 & 0.061 & 0.078 \\
\hline & Usage Per. & 0.012 & -0.066 & -0.069 & -0.094 \\
\hline \multirow{4}{*}{ Independent variables } & CPX & & -0.071 & 0.011 & $-0.615^{* *}$ \\
\hline & OVL & & $-0.177^{* *}$ & 0.056 & $-0.800^{* * *}$ \\
\hline & IVS & & $-0.151^{* *}$ & $-0.133^{* *}$ & $-0.544^{* * *}$ \\
\hline & $\mathrm{UCT}$ & & $-0.228^{* * *}$ & -0.105 & $-0.420 * *$ \\
\hline Moderating variable & DTSE & & & $0.470 * * *$ & $0.661^{* * *}$ \\
\hline \multirow{4}{*}{ Interactions } & CPX *DTSE & & & & $-0.357^{* *}$ \\
\hline & OVL *DTSE & & & & $-0.498^{* *}$ \\
\hline & IVS *DTSE & & & & -0.201 \\
\hline & UCT ${ }^{*} \mathrm{DTSE}$ & & & & -0.167 \\
\hline $\mathrm{R}^{2}$ & & 0.024 & 0.163 & 0.314 & 0.385 \\
\hline $\mathrm{F}$ & & 1.594 & 6.255 & 12.996 & 12.110 \\
\hline$\Delta \mathrm{F}$ & & & - & 20.81 & 3.73 \\
\hline
\end{tabular}




\section{Discussion and Conclusions}

\subsection{Summary and Discussion}

The study aims to verify the impact of digital technostress and digital technology selfefficacy on the usage intention of fintech services among Chinese Gen $\mathrm{Z}$ consumers, who are the most exposed to advanced digital technologies, such as fintech [16]. In particular, as consumers are currently experiencing technostress due to the rapid development of digital technologies, including fintech, the study focused on the negative effects of technostress on the usage intention of fintech services. In addition, the study assumed that digital technology self-efficacy not only has a direct positive effect on fintech usage intention but also a moderating effect on the relationship between digital technostress and fintech usage intention. The summary of the empirical analysis results is as follows.

First, it was found that all four sub-dimensions of DTS (CPX, OVL, IVS, and UCT) had a statistically significant negative effect on FUI. The abovementioned empirical analysis results are consistent with the results of previous research [37-41]. It was found that Chinese Gen Z consumers with high perception of CPX, OVL, IVS, and UCT show a lower intention to use fintech services. Therefore, Hypothesis 1 to 4 were supported. Next, the DTSE of Chinese Gen Z consumers was found to increase their intention to use Fintech service, which is consistent with previous research results $[54,55,57]$. Therefore, hypotheses 5 was supported. Lastly, DTSE was found to significantly lower the negative impact of CPX and OVL on FUI, while DTSE has not shown statistically significant interaction effects with IVS and UCT on FUI. Therefore, hypotheses 6 and 7 were supported, while hypotheses 8 and 9 were rejected.

The study showed that Gen $Z$ consumers experience digital technostress due to rapidly changing digital technology, and the digital technostress negatively affect fintech usage intention of Gen $Z$ consumers. Therefore, the empirical results of the study are contradicted to the previous study's argument that Gen $Z$ consumers generally show a very positive psychological response to digital technology [16,71]. According to the above study findings, digital marketers and researchers should consider novel approaches to predict fintech usage behavior of Gen Z consumers. Meanwhile, the study also found that DTSE has moderating effects on the negative impacts of CPX and OVL on FUI. The interaction effect between DTSE and technostress among Gen Z consumers is a very new finding for digital marketing research field. This seems because Gen Z consumers with high DTSE have self-belief to respond the negative effects of techno-complexity and techno-overload on fintech usage intention in the consumer's individual level. However, the study found that DTSE has no moderating effect on the negative impacts of IVS and UCT on FUI. It seems because techno-invasion and techno-uncertainty are structural problem that is difficult to respond in the consumer's individual level. Therefore, the study results can offer digital marketers with practical implications that they should actively utilize digital technology self-efficacy to manage technostress which can be handled in the individual-level, such as technocomplexity and techno-overload. In addition, digital marketers must also prepare special measures to reduce the negative impact of structural technostress, such as techno-invasion and techno-uncertainty, on Gen $\mathrm{Z}$ consumers fintech usage intention.

\subsection{Conclusions}

The study results not only offer practical implications to fintech marketers but also contribute academic implications to the digital marketing research field. First, according to results of the study, fintech marketers should develop media-based materials, such as pictures, animations, or videos, through which consumers can more easily and quickly understand the features of new digital technologies and how to use them, by considering the behavioral traits of Gen $\mathrm{Z}$ consumers. Second, fintech marketers should present higher level of norms and regulations for personal privacy and security issues. Third, it is important to be careful not to directly expose consumers to excessively frequent updates or digital technology changes and to establish a more meticulous marketing strategy to reduce the increased cognitive and emotional burden on consumers due to digital technology 
changes. Such marketing efforts can lower the digital technology technostress of consumers, contributing to forming consumers' positive attitude and behavior to a wider variety of fintech services. Finally, fintech marketers should focus on a marketing strategy that can increase Gen Z consumers' DTSE as the study found a significant positive direct effect of DTSE on FUI and moderating effects of DTSE on the relationship between DTS and FUI. Therefore, fintech marketers should provide various ways for Gen Z consumers to understand and learn new digital technologies with ease and enjoyment through various media means to increase a level of Gen Z consumers' DTSE. In addition, digital marketing researchers need to have a broader perspective to find more various impediments, such as technostress, which negatively influence consumers' adoption and usage behavior of new digital technologies like fintech. In particular, examining the impacts of new negative factors, such as technostress, in a new consumer segment like Gen Z can contribute to broadening the academic scope of digital marketing.

Despite the academic and practical contributions of this study presented above, this study has the following limitations. First, the number of samples used in this study is small compared to China's population; therefore, future research will have to collect a larger amount of data for empirical analysis. In addition, the study results should be carefully interpreted as the sample size is not large enough. Second, in the case of the technostress variable, there will be large differences according to consumers' age groups; it is thus necessary to compare different impacts of DTSE on fintech behavior between age groups in future research. Third, the study has limitations in reflecting demographic and regional diversity in China; therefore, future research should consider collecting data in various consumer segments in China to compare the distinctions of fintech usage behavior. Finally, this study used consumers' comprehensive and general usage intention of various fintech services as outcome variables. However, a wide variety of new fintech services have recently been launched in the Chinese market which are being widely accepted by consumers. Therefore, future research should consider the differences in various types of fintech services and fintech consumption behavior for a more comprehensive understanding of Chinese fintech behavior.

Funding: This study received no external funding.

Institutional Review Board Statement: Ethical review and approval were waived for this study, because the study didn't directly confront the online survey respondents and use personally identifiable information either. In addition, the study didn't collect or record "sensitive information" from the respondents, so it can't directly or indirectly identify the respondents at all.

Informed Consent Statement: Not applicable.

Data Availability Statement: Not applicable.

Acknowledgments: I would like to thank Dongguk University Gyeongju Campus for supporting the study.

Conflicts of Interest: The author declares no conflict of interest.

\section{References}

1. Gomber, P.; Koch, J.A.; Siering, M. Digital finance and FinTech: Current research and future research directions. J. Bus. Econ. 2017, 87, 537-580. [CrossRef]

2. Walden, S. What is FinTech and How Does It Affect How I Bank? Available online: https://www.forbes.com/advisor/banking/ what-is-fintech/ (accessed on 27 January 2021).

3. Gabor, D.; Brooks, S. The digital revolution in financial inclusion: International development in the fintech era. New Pol. Econ. 2017, 22, 423-436. [CrossRef]

4. Gomber, P.; Kauffman, R.J.; Parker, C.; Weber, B.W. On the FinTech revolution: Interpreting the forces of innovation, disruption, and transformation in financial services. J. Manag. Inf. Syst. 2018, 35, 220-265. [CrossRef]

5. Mittal, S.; Lloyd, J.; The Rise of FinTech in China: Redefining Financial Services. EY and DBS Bank, November. Available online: https:/ / www.finyear.com/attachment/785371/ (accessed on 12 January 2021).

6. Chen, L. From FinTech to finlife: The case of FinTech development in China. China Econ. J. 2016, 9, 225-239. [CrossRef] 
7. Kukreja, G. FinTech adoption in China: Challenges, regulations, and opportunities. In Innovative Strategies for Implementing FinTech in Banking; IGI Global: Hershey, PA, USA, 2021; pp. 166-173. [CrossRef]

8. Huang, Y. Fintech Development in the People's Republic of China and Its Macroeconomic Implications. 2020. Available online: https:/ / www.adb.org/publications/fintech-development-prc-its-macroeconomic-implications (accessed on 10 December 2020).

9. Statista Research Department. FinTech in China: Statistics \& Facts. Available online: https://www.statista.com/topics/6893 / fintech-in-china/ (accessed on 22 January 2021).

10. Hua, X.; Huang, Y. Understanding China's FinTech sector: Development, impacts and risks. Eur. J. Fin. 2021, 27, 321-333. [CrossRef]

11. CNNIC. Statistical Report on Internet Development in China. Available online: https://cnnic.com.cn/IDR/ReportDownloads/ 202012/P020201201530023411644.pdf (accessed on 22 February 2021).

12. Zhou, T. An empirical examination of continuance intention of mobile payment services. Dec. Supp. Syst. 2013, 54, 1085-1091. [CrossRef]

13. Chuang, L.M.; Liu, C.-C.; Kao, H.-K. The Adoption of Fintech Service: TAM Perspective. Int. J. Manag. Admin. Sci. 2016, 3, pp. 1-15. Available online: https:/ /www.ijmas.org/3-7/IJMAS-3601-2016.pdf (accessed on 2 October 2020).

14. Wang, Z.; Guan, Z.; Hou, F.; Li, B.; Zhou, W. What determines customers' continuance intention of FinTech? Evidence from YuEbao. Ind. Manag. Data Syst. 2019, 119, 1625-1637. [CrossRef]

15. Brod, C. Technostress: The Human Cost of the Computer Revolution; Basic Books: New York, NY, USA, 1984.

16. Tim, S. Millennial Shoppers are Old News: Looking Ahead to Gen Z. Available online: https://www.gfk.com/blog/2014/09/ millennial-shoppers-are-old-news-looking-ahead-to-gen-z (accessed on 2 November 2020).

17. EY. Global FinTech Adoption Index 2019. Available online: https://assets.ey.com/content/dam/ey-sites/ey-com/en_gl/topics/ banking-and-capital-markets/ey-global-fintech-adoption-index.pdf (accessed on 11 January 2021).

18. Gruin, J.; Knaack, P. Not just another shadow bank: Chinese authoritarian capitalism and the "developmental" promise of digital financial innovation. New Pol. Econ. 2020, 25, 370-387. [CrossRef]

19. Zhang, Y.Z.; Rohlfer, S.; Rajasekera, J. An eco-systematic view of cross-sector FinTech: The case of Alibaba and Tencent. Sustainability 2020, 12, 8907. [CrossRef]

20. Lloyd, J. What Is Next for Asia in FinTech Adoption. Available online: https://www.ey.com/en_gl/banking-capital-markets/ what-is-next-for-asia-in-fintech-adoption (accessed on 28 January 2021).

21. FSEC, E-Finance and Financial Security 2019-10. Available online: http:/ /webcache.googleusercontent.com/search?q=cache: VsFCYLiNa80J:www.fsec.or.kr/common/proc/fsec/bbs/146/fileDownLoad/2108.do+\&cd=2\&hl=ko\&ct=clnk\&gl=kr $($ accessed on 14 January 2021).

22. Cannon, W. B. The Wisdom of the Body; W.W. Norton \& Company: New York, NY, USA, 1932.

23. Selye, H. The Stress of Life; McGraw-Hill Book Company: New York, NY, USA, 1956.

24. Cooper, C.L.; Marshall, J. Occupational sources of stress: A review of the literature relating to coronary heart disease and mental ill health. J. Occup. Psychol. 1976, 49, 11-28. [CrossRef]

25. Beehr, T.A.; Newman, J.E. Job stress, employee health, and organizational effectiveness: A facet analysis, model, and literature review 1. Pers. Psychol. 1978, 31, 665-699. [CrossRef]

26. Beehr, T.A.; Johnson, L.B.; Nieva, R. Occupational stress: Coping of police and their spouses. J. Organ. Behav. 1995, 16, 3-25. [CrossRef]

27. Kanner, A.D.; Coyne, J.C.; Schaefer, C.; Lazarus, R.S. Comparison of two modes of stress measurement: Daily hassles and uplifts versus major life events. J. Behav. Med. 1981, 4, 1-39. [CrossRef] [PubMed]

28. Lazarus, R.S.; Folkman, S. Stress, Appraisal, and Coping; Springer: New York, NY, USA, 1984.

29. McCauley, C.D.; Ruderman, M.N.; Ohlott, P.J.; Morrow, J.E. Assessing the developmental components of managerial jobs. J. Appl. Psychol. 1994, 79, 544. [CrossRef]

30. Hudiburg, R.A. Psychology of computer use: Computer technology hassles scale: Revision, reliability, and some correlates. Psych. Rep. 1989, 65, 1387-1394. [CrossRef]

31. Shu, Q.; Tu, Q.; Wang, K. The impact of computer self-efficacy and technology dependence on computer-related technostress: A social cognitive theory perspective. Int. J. Hum. Comp. Int. 2011, 27, 923-939. [CrossRef]

32. Arnetz, B.B.; Wiholm, C. Technological stress: Psychophysiological symptoms in modern offices. J. Psych. Res. 1997, 43, 35-42. [CrossRef]

33. Weil, M.M.; Rosen, L.D. Technostress: Coping with Technology @WORK @HOME @PLAY; John Wiley \& Sons: New York, NY, USA, 1997.

34. Salanova, M.; Llorens, S.; Cifre, E. The dark side of technologies: Technostress among users of information and communication technologies. Int. J. Psych. 2013, 48, 422-436. [CrossRef]

35. Tarafdar, M.; Tu, Q.; Ragu-Nathan, B.; Ragu-Nathan, T.S. The impact of technostress on role stress and productivity. J. Manag. Inf. Syst. 2007, 24, 301-328. [CrossRef]

36. Brillhart, P.E. Technostress in the workplace managing stress in the electronic workplace. J. Amer. Acad. Bus. $2004,5,302-307$.

37. Ayyagari, R.V.G.; Purvis, R.L. Technostress: Technology antecedents and implications. Mis. Quart. 2011, 35, 831-858. [CrossRef]

38. Ragu-Nathan, T.S.; Tarafdar, M.; Ragu-Nathan, B.S.; Tu, Q. The consequences of technostress for end users in organizations: Conceptual development and empirical validation. Inf. Syst. Res. 2008, 19, 417-433. [CrossRef] 
39. Lee, H.S.; Lee, S.J. An Empirical Study on the Discontinuance Intention of Smart Device in Post Adoption Context. J. Knowl. Inf. Tech. 2014, 9, pp. 13-21. Available online: https://www.kci.go.kr/kciportal/ci/sereArticleSearch/ciSereArtiView.kci? sereArticleSearchBean.artiId=ART001852153 (accessed on 14 January 2021).

40. Çoklar, A.N.; Şahin, Y.L. Technostress levels of social network users based on ICTs in Turkey. Eur. J. Soc. Sci. 2011, 23, 171-182.

41. Chen, J.V.; Tran, A.; Nguyen, T. Understanding the discontinuance behavior of mobile shoppers as a consequence of technostress: An application of the stress-coping theory. Comput. Hum. Behav. 2019, 95, 83-93. [CrossRef]

42. Stokols, D.; Altman, I. Handbook of Environmental Psychology; Wiley: New York, NY, USA, 1987.

43. Zhang, S.; Zhao, L.; Lu, Y.; Yang, J. Do you get tired of socializing? An empirical explanation of discontinuous usage behaviour in social network services. Inf. Manag. 2016, 53, 904-914. [CrossRef]

44. Krafft, M.; Arden, C.M.; Verhoef, P.C. Permission marketing and privacy concerns-Why do customers (not) grant permissions? J. Int. Mark. 2017, 39, 39-54. [CrossRef]

45. Luqman, A.; Cao, X.; Ali, A.; Masood, A.; Yu, L. Empirical investigation of Facebook discontinues usage intentions based on SOR paradigm. Comput. Hum. Behav. 2017, 70, 544-555. [CrossRef]

46. Bandrua, A. Social Foundations of Thought and Action; Prentice: Englewood Cliffs, NJ, USA, 1986.

47. Bandura, A. Self-efficacy: Toward a unifying theory of behavioral change. Psychol. Rev. 1977, 84, 191. [CrossRef]

48. Bandura, A. Self-Efficacy: The Exercise of Control; Freeman: New York, NY, USA, 1997.

49. Bagozzi, R.P. Salesforce performance and satisfaction as a function of individual difference, interpersonal, and situational factors. J. Mark. Res. 1978, 15, 517-531. [CrossRef]

50. Gist, M.E.; Schwoerer, C.; Rosen, B. Effects of alternative training methods on self-efficacy and performance in computer software training. J. Appl. Psych. 1989, 74, 884-891. [CrossRef]

51. Martocchio, J.J. Effects of conceptions of ability on anxiety, self-efficacy, and learning in training. J. Appl. Psych. 1994, 79, 819-825. [CrossRef] [PubMed]

52. Shea, C.M.; Howell, J.M. Charismatic leadership and task feedback: A laboratory study of their effects on self-efficacy and task performance. Leadersh. Quart. 1993, 10, 375-396. [CrossRef]

53. Lee, J. An Exploratory Analysis of the Antecedents of Self-Efficacy in the Work Environment. J. Oganz. Mang. 2003, 27, pp. 175-198. Available online: http:/ / scholar.dkyobobook.co.kr/ searchExtDetail.laf?barcode $=4010016697318 \&$ vendorGb=01\&academyCd=16 (accessed on 14 January 2021).

54. Cassidy, S.; Eachus, P. Developing the computer user self-efficacy (CUSE) scale: Investigating the relationship between computer efficacy, gender, and experience. J. Edu. Comp. Res. 2002, 26, 133-153. [CrossRef]

55. Eastin, M.S.; Larose, R. Internet self-efficacy and the psychology of the digital divide. J. Comp. Med. Com. 2000, 6, 1-18. [CrossRef]

56. Venkatesh, V.; Davis, F.D. A model of the antecedents of perceived ease of use: Development and test. Dec. Sci. 1996, 27, 451-481. [CrossRef]

57. Compeau, D.R.; Higgins, C.A. Computer Self-efficacy: Development of a measure and initial test. Mis. Quart. 1995, 19, 189-211. [CrossRef]

58. Rogers, E.M. Diffusion of Innovations; Simon and Schuster: New York, NY, USA, 2010.

59. Jerusalem, M.; Mittag, W. Self-efficacy in stressful life transitions. In Self-Efficacy in Changing Societies; Bandura, A., Ed.; Cambridge University Press: Cambridge, UK, 1995; pp. 177-201.

60. Lu, C.Q.; Siu, O.L.; Cooper, C.L. Managers' occupational stress in China: The role of self-efficacy. Pers. Individ. Differ. 2005, 38, 569-578.

61. Julious, S.A. Sample size of 12 per group rule of thumb for a pilot study. Pharm. Stat. 2005, 4, 287-291. [CrossRef]

62. Browne, R.H. On the use of a pilot sample for sample size determination. Stat. Med. 1995, 14, 1933-1940. [CrossRef]

63. Egea, J.M.O.; González, M.V.R. Explaining physicians' acceptance of EHCR systems: An extension of TAM with trust and risk factors. Comp. Hum. Behav. 2011, 27, 319-332. [CrossRef]

64. Tarafdar, M.; Tu, Q.; Ragu-Nathan, T.S.; Ragu-Nathan, B.S. Crossing to the dark side: Examining creators, outcomes, and inhibitors of technostress. Commun. ACM 2011, 54, 113-120. [CrossRef]

65. Zedeck, S. Problems with the use of "moderator" variables. Psychol. Bull. 1971, 76, 295-310. [CrossRef]

66. Fornell, C.; Larcker, D.F. Evaluating structural equations models with unobservable variables and measurement error. J. Mark. Res. 1981, 18, 39-50. [CrossRef]

67. Hair, J.F.; Sarstedt, M.; Pieper, T.M.; Ringle, C.M. The use of partial least squares structural equation modeling in strategic management research: A review of past practices and recommendations for future applications. Long Range Plan. 2012, 45, 320-340. [CrossRef]

68. Grewal, R.; Cote, J.A.; Baumgartner, H. Multicollinearity and Measurement Error in Structural Equation Models: Implications for Theory Testing. Mark. Sci. 2004, 23, 519-529. [CrossRef]

69. Baron, R.M.; Kenny, D.A. The moderator-mediator variable distinction in social psychological research: Conceptual, strategic, and statistical considerations. J. Personal. Soc. Psychol. 1986, 51, 1173-1182. [CrossRef]

70. Cohen, J.; Cohen, P.; Stephen, G.W.; Leona, S.A. Applied Multiple Regression/Correlation Analysis for the Behavioral Sciences, 3rd ed.; Lawrence Erlbaum Associates, Inc.: Mahwah, NJ, USA, 2002.

71. Vasilios, P.; Nikolaos, S.; Anestis, K. Generation Z consumers' expectations of interactions in smart retailing: A future agenda. J. Comp. Hum. Behav. 2017, 77, 374-381. [CrossRef] 